\title{
Lipoteichoic acid upregulates NF-кB and proinflammatory cytokines by modulating $\beta$-catenin in bronchial epithelial cells
}

\author{
JAEWOONG JANG ${ }^{1}$, WONYONG KIM ${ }^{1}$, KIJEONG KIM ${ }^{1}$, SANG-IN CHUNG ${ }^{1}$, \\ YAE JIE SHIM $^{2}$, SEOK-MIN KIM ${ }^{3}$ and YOOSIK YOON ${ }^{1}$ \\ ${ }^{1}$ Department of Microbiology, Chung-Ang University College of Medicine, Seoul 156-756; \\ ${ }^{2}$ College of General Studies, Sangmyung University, Seoul 110-743; \\ ${ }^{3}$ School of Mechanical Engineering, Chung-Ang University, Seoul 156-756, Republic of Korea
}

Received September 18, 2014; Accepted May 15, 2015

DOI: $10.3892 / \mathrm{mmr} .2015 .3965$

\begin{abstract}
Lipoteichoic acid (LTA) is a major cell wall component and virulence factor of gram-positive bacteria. The present study investigated the LTA-induced inflammatory response of BEAS-2B human bronchial epithelial cells, and detected the expression levels of proinflammatory cytokines interleukin (IL)-6, IL-8, IL-1 $\beta$, tumour necrosis factor- $\alpha$ and monocyte chemotactic protein-1, the upregulation of NF- $\kappa B$,

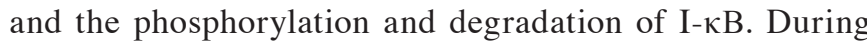
the LTA-induced inflammatory response of the BEAS-2B human bronchial epithelial cells, the activity levels of the $\beta$-catenin-dependent promoter, and the protein expression levels of $\beta$-catenin were significantly upregulated, whereas $\beta$-catenin phosphorylation and the expression levels of AXIN were significantly downregulated. Following knockdown of $\beta$-catenin by small interfering (si)RNA transfection, both the LTA-induced protein expression levels of NF- $\kappa \mathrm{B}$ and the LTA-induced activity levels of the NF- $\kappa B$-dependent promoter were significantly reduced. Similarly, a marked reduction in $\mathrm{I}-\kappa \mathrm{B}$ phosphorylation and degradation was observed following $\beta$-catenin knockdown. The expression levels of the LTA-induced proinflammatory cytokines were also significantly reduced following $\beta$-catenin siRNA. These results suggest that $\beta$-catenin has a significant role in the regulation of NF- $\mathrm{\kappa B}$ activity and proinflammatory cytokine expression during the LTA-induced inflammatory response of bronchial epithelial cells.
\end{abstract}

\footnotetext{
Correspondence to: Professor Yoosik Yoon or Professor Sang-In Chung, Department of Microbiology, Chung-Ang University College of Medicine, 84 Heukseok-ro, Dongjak-gu, Seoul 156-756, Republic of Korea

E-mail: thanks@cau.ac.kr

E-mail: sichung@cau.ac.kr
}

Key words: lipoteichoic acid, $\beta$-catenin, bronchial epithelial cells, $\mathrm{NF}-\kappa \mathrm{B}$, cytokine, inflammation

\section{Introduction}

Lipoteichoic acids (LTA) are polymers composed of alternating units of polyhydroxy alkanes, including glycerol and ribitol, and phosphoric acids, which together form phosphodiester units in the envelop of gram-positive bacteria (1). LTA is released from bacterial cells following bacteriolysis induced by leukocyte lysozymes or $\beta$-lactam antibiotics, and binds to target cells either non-specifically via membrane phospholipids, or specifically via CD14 and Toll-like receptor 2, resulting in the release of reactive oxygen and nitrogen species, acid hydrolase, proteinase, bactericidal peptides, and proinflammatory cytokines (2). Through these mechanisms LTA is involved in the pathophysiology of inflammation and post-infectious sequelae such as septic shock, adult respiratory distress syndrome, and toxic shock syndrome, thus suggesting that LTA is one of the major virulence factors of gram-positive bacteria (2-4).

The bronchial epithelium is continuously exposed to gram-positive bacteria that induce inflammation, such as Streptococcus pneumoniae, which initiate the release of interleukin (IL)-8 in human lung epithelial cells via nuclear factor (NF)- $\mathrm{kB}$ recruitment to the IL-8 promoter (5). LTA is a major virulence factor of Streptococcus pneumoniae, and activates $\mathrm{NF}-\kappa \mathrm{B}$ in order to induce inflammatory responses in the respiratory system, via a complex signaling pathway involving Toll-like receptors $(6,7)$. In numerous respiratory diseases, the bronchial epithelium induces an inflammatory response through the production of proinflammatory cytokines (8). Therefore, ascertaining which genes and proteins are involved in the regulation of the inflammatory response of bronchial epithelial cells is crucial for the prevention and treatment of respiratory diseases (8).

$\beta$-catenin is a member of the WNT/ $\beta$-catenin signaling pathway, which regulates various biological processes including cellular proliferation, differentiation, and development (9). A previous study showed that $\beta$-catenin modulated the inflammatory response of bronchial epithelial cells treated with lipopolysaccharide (LPS), which is a virulence factor of gram-negative bacteria (10). The present study was conducted to investigate if $\beta$-catenin also has a significant role in the LTA-induced inflammatory response in BEAS-2B human bronchial epithelial cells. 


\section{Materials and methods}

Cell culture. The BEAS-2B human bronchial epithelial cell line was purchased from the American Type Culture Collection (Manassas, VA, USA), and cultured in Dulbecco's modified Eagle's medium (Sigma-Aldrich, St. Louis, MO, USA) supplemented with $10 \%$ fetal bovine serum (Gibco Life Technologies, Grand Island, NY, USA), $100 \mu \mathrm{g} / \mathrm{ml}$ streptomycin, and $100 \mathrm{U} / \mathrm{ml}$ penicillin (Lonza, Walkersville, $\mathrm{MD}, \mathrm{USA})$ at $37^{\circ} \mathrm{C}$ in an atmosphere containing $5 \% \mathrm{CO}_{2}$. The BEAS-2B human bronchial epithelial cells were treated with LTA from Staphylococcus aureus (Sigma-Aldrich), in order to induce an inflammatory response. LTA was treated at a concentration of $100 \mu \mathrm{g} / \mathrm{ml}$ for up to $3 \mathrm{~h}$ after suitable treatment conditions were experimentally determined.

Reverse transcription-quantitative polymerase chain reaction $(R T-q P C R)$. The mRNA expression levels of the proinflammatory cytokines were measured by RT-qPCR, as previously described (10). Briefly, the BEAS-2B human bronchial epithelial cells were cultured in 12-well plates, and total RNA was extracted using an RNeasy kit (Qiagen GmbH, Hilden, Germany). Total RNA $(1 \mu \mathrm{g})$ was then reverse-transcribed at $37^{\circ} \mathrm{C}$ using a cDNA Reverse Transcription kit (Applied Biosystems Life Technologies, Foster City, CA, USA). Briefly, the reaction was performed in a final volume of $20 \mu \mathrm{l}$, which included reverse transcriptase reaction buffer, $100 \mathrm{mM}$ dNTP mix, random primers, MultiScribe reverse transcriptase, RNase inhibitor and total RNA. The reaction mixtures were heated at $25^{\circ} \mathrm{C}$ for $10 \mathrm{~min}, 37^{\circ} \mathrm{C}$ for $120 \mathrm{~min}$ and $85^{\circ} \mathrm{C}$ for 5 min. RT-qPCR was performed in triplicate using a StepOne PCR system (Applied Biosystems Life Technologies), in a final volume of $20 \mu \mathrm{l}$ containing TaqMan ${ }^{\circledR}$ Gene Expression Master mix (Applied Biosystems Life Technologies), an optimized concentration of each primer, $250 \mathrm{nM}$ TaqMan ${ }^{\circledR}$ probe, and $2.0 \mu \mathrm{l}$ cDNA reaction mixture. The reaction mixtures were preheated at $95^{\circ} \mathrm{C}$ for $10 \mathrm{~min}$ in order to activate the enzyme, and then subjected to 40 cycles of melting at $95^{\circ} \mathrm{C}$ for $15 \mathrm{sec}$, prior to annealing/extension at $60^{\circ} \mathrm{C}$ for $1 \mathrm{~min}$. RT-qPCR efficiencies were $\sim 100 \%$. Assay-on-demand gene expression products (Applied Biosystems Life Technologies) were used to evaluate the mRNA expression levels of IL-6 (Hs00174131/m1), IL-8 (Hs99999034/m1), IL-1 $\beta$ (Hs01555410/m1), tumor necrosis factor (TNF)- $\alpha$ (Hs01113624/m1), monocyte chemoattractant protein (MCP)-1 (Hs00234140/m1), and 18S rRNA (Hs99999901/m1). For each sample, the mRNA expression levels were normalized to $18 \mathrm{~S}$ rRNA expression levels, and the ratios of normalized mRNA to untreated control sample mRNA were determined using the comparative cycle threshold (Ct) method (11).

Promoter reporter assay. The transcriptional activity levels induced by $\mathrm{NF}-\kappa \mathrm{B}$ or $\beta$-catenin were determined using a promoter reporter assay as previously described (10). In order to measure NF- $\mathrm{NB}$-dependent transcriptional activity, $2 \times 10^{5}$ BEAS-2B human bronchial epithelial cells were co-transfected at a 1:50 ratio with a pGL 4.32 vector (Promega Corporation, Madison, WI, USA) containing a firefly luciferase reporter gene linked to a promoter containing the $\mathrm{NF}-\kappa \mathrm{B}$ response element, and a pGL 4.17 vector (Promega Corporation) containing a
Renilla luciferase reporter gene using Lipofectamine 2000 reagent (Invitrogen Life Technologies, Carlsbad, CA, USA). The cells were harvested $24 \mathrm{~h}$ post-transfection, and luciferase activity was measured using a Dual-Luciferase Reporter Assay system (Promega Corporation). In order to measure $\beta$-catenin-dependent transcriptional activity, the BEAS-2B human bronchial epithelial cells were co-transfected at a 1:50 ratio with a TOP flash vector (EMD Millipore, Billerica, MA, USA) containing a firefly luciferase reporter gene linked to a promoter containing the $\beta$-catenin response element, and a pGL 4.17 vector containing a Renilla luciferase reporter gene. For each assay, the firefly luciferase activity was normalized to the Renilla luciferase activity in order to identify variations in transfection efficiency.

Western blotting. The BEAS-2B human bronchial epithelial cells were lysed with ice-cold radioimmunoprecipitation assay buffer containing $25 \mathrm{mM}$ Tris- $\mathrm{HCl}$ pH 7.6, $150 \mathrm{mM} \mathrm{NaCl}$, $1 \%$ Nonidet P-40, $1 \%$ sodium deoxycholate, $0.1 \%$ SDS, and a protease inhibitor cocktail (Sigma-Aldrich), and the insoluble materials were subsequently removed by centrifugation at $20,000 \mathrm{x} \mathrm{g}$ for $20 \mathrm{~min}$ at $4^{\circ} \mathrm{C}$. The protein concentrations were determined using a bicinchoninic acid protein assay kit (Pierce, Rockford, IL, USA). A total of $50 \mu \mathrm{g}$ lysate proteins were electrophoresed in 12\% SDS-PAGE and transferred onto nitrocellulose membranes (Bio-Rad Laboratories, Inc., Hercules, CA, USA). Protein expression was detected using 1:1,000 dilutions of primary antibodies, including anti $\mathrm{NF}-\kappa \mathrm{B}$ (cat. no. 13681, Cell Signaling Technology, Inc., Danvers, MA, USA), anti I- $\kappa$ B (cat. no. 9242, Cell Signaling Technology, Inc.), anti phospho I- $\kappa$ B (cat. no. 9246, Cell Signaling Technology, Inc.) and anti $\beta$-catenin (cat. no. 610153, BD Biosciences, San Jose, CA, USA) overnight at $4^{\circ} \mathrm{C}$, followed by $1: 1,000$ dilutions of horseradish peroxidase-conjugated anti-mouse (cat. no. 7076S, Cell Signaling Technology, Inc.) or anti-rabbit (cat. no. 7074S, Cell Signaling Technology, Inc.) secondary antibody for $2 \mathrm{~h}$ at room temperature. Peroxidase activity was visualized using an ECL kit (Bio-Rad Laboratories Inc.). Anti- $\beta$-actin antibody (Santa Cruz Biotechnology, Inc., Dallas, TX, USA) was used as the loading control for total cell lysates.

Small interfering (si)RNA transfection. The BEAS-2B human bronchial epithelial cells were grown to $70 \%$ confluence and transfected with $50 \mathrm{nM}$ control siRNA or $\beta$-catenin siRNA (Santa Cruz Biotechnology, Inc.) mixed with Lipofectamine ${ }^{\circledR}$ RNAiMAX Transfection reagent (Invitrogen Life Technologies), all of which were suspended in Opti-MEM ${ }^{\circledR}$ medium (Invitrogen Life Technologies). Following an incubation period of $18 \mathrm{~h}$, the transfected cells $\left(2 \times 10^{5}\right.$ cells $)$ were treated with LTA in order to induce an inflammatory response.

Statistical analysis. All data are expressed as the mean \pm standard deviation, and all experiments were performed in triplicate. Statistically significant differences between treated and untreated samples were detected using unpaired t-tests. $\mathrm{P}<0.05$ was considered to indicate a statistically significant difference. All statistical analyses were performed using SPSS 18.0 (SPSS, Chicago, IL, USA). 
A

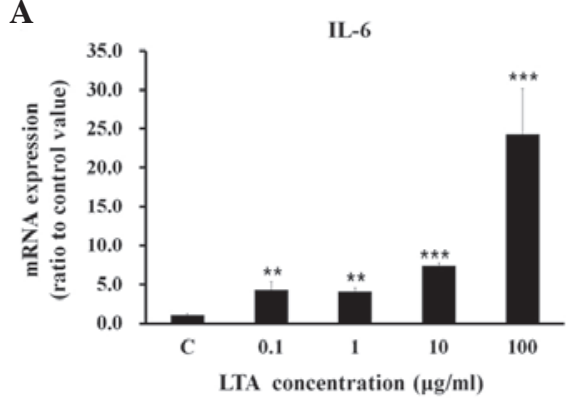

D

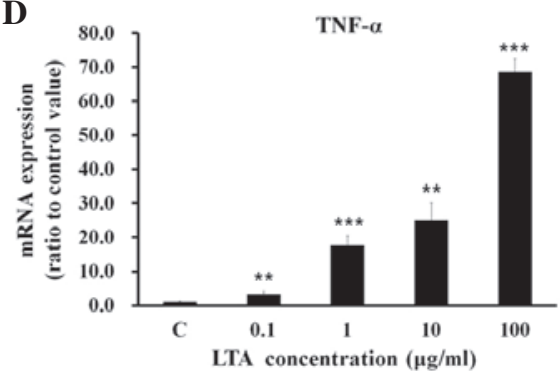

IL-8

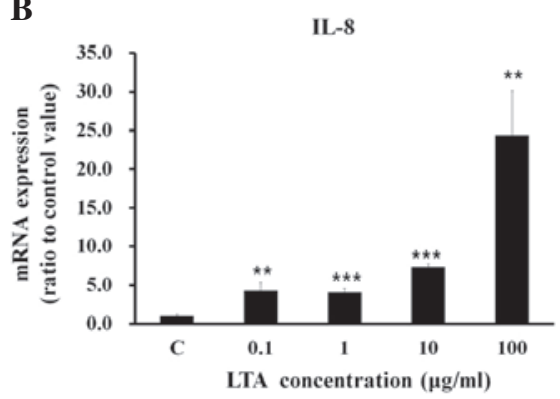

$\mathbf{E}$
C

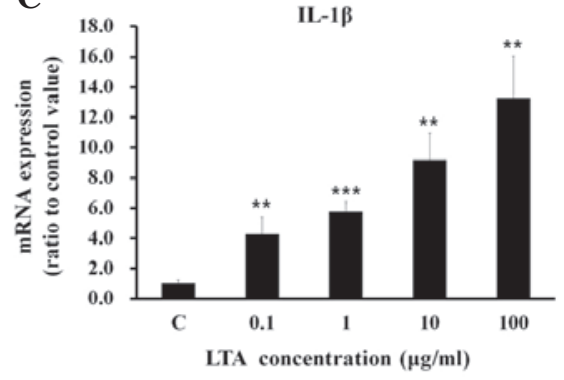

MCP-1

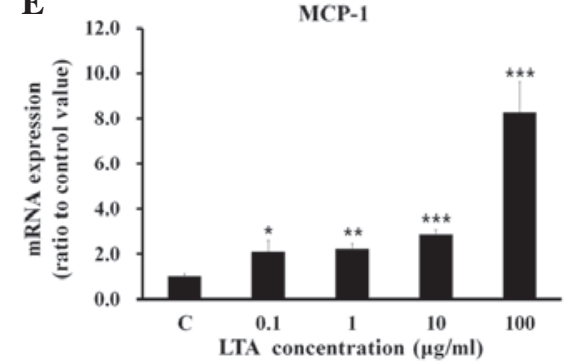

Figure 1. Effects of various lipoteichoic acid (LTA) concentrations on mRNA expression of proinflammatory cytokines. The BEAS-2B human bronchial epithelial cells were treated with LTA at various concentrations ranging from $0.1-100 \mu \mathrm{g} / \mathrm{ml}$ for up to $3 \mathrm{~h}$, and the mRNA expression levels of the proinflammatory cytokines: (A) Interleukin (IL)-6; (B) IL-8; (C) IL-1B; (D) tumor necrosis factor (TNF)- $\alpha$; (E) monocyte chemoattractant protein (MCP)-1 were measured by reverse transcription-quantitative polymerase chain reaction. Data are expressed as the mean \pm standard deviation. ${ }^{*} \mathrm{P}<0.05,{ }^{* * *} \mathrm{P}<0.01$, and ${ }^{* * * *} \mathrm{P}<0.001, \mathrm{vs}$. the untreated control cells.
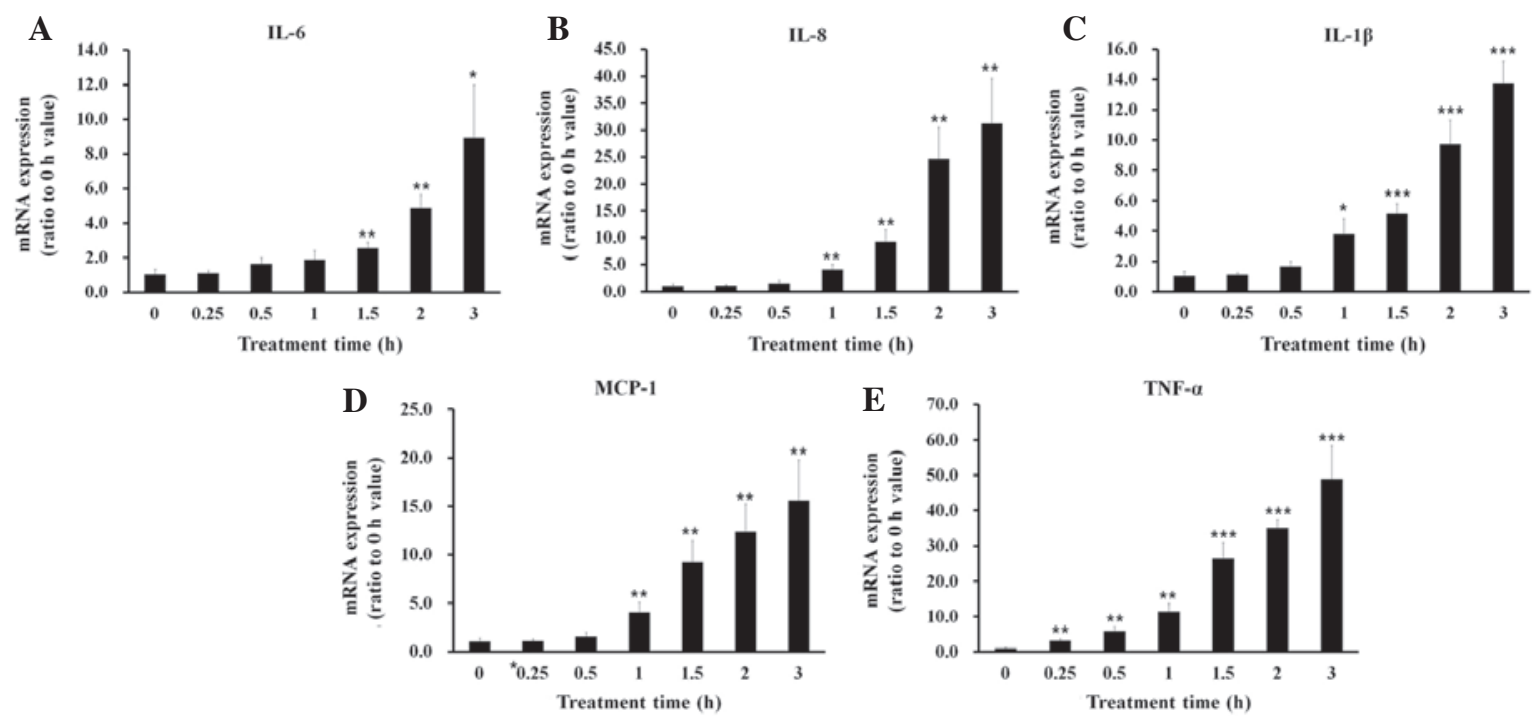

Figure 2. Time course of lipoteichoic acid (LTA)-induced mRNA expression of proinflammatory cytokines. The BEAS-2B human bronchial epithelial cells were treated with $100 \mu \mathrm{g} / \mathrm{ml}$ LTA for various time periods up to $3 \mathrm{~h}$, and the mRNA expression levels of proinflammatory cytokines: (A) Interleukin (IL)-6; (B) IL-8; (C) IL-1 $\beta$; (D) monocyte chemoattractant protein (MCP)-1; and (E) tumor necrosis factor (TNF)- $\alpha$, were measured by reverse transcription quantitative polymerase chain reaction. Data are expressed as the mean \pm standard deviation. ${ }^{*} \mathrm{P}<0.05,{ }^{* *} \mathrm{P}<0.01$, and ${ }^{* * * *} \mathrm{P}<0.001$, vs. the untreated control ( 0 ) cells.

\section{Results}

LTA-induces $m R N A$ expression levels of proinflammatory cytokines in bronchial epithelial cells. The mRNA expression of proinflammatory cytokines IL-6, IL-8, IL-1 $\beta$, TNF- $\alpha$, and MCP-1 was induced in a dose-dependent manner by treating the BEAS-2B human bronchial epithelial cells with various concentrations of LTA, ranging from $0.1-100 \mu \mathrm{g} / \mathrm{ml}$ (Fig. 1). All subsequent experiments were conducted using LTA at a concentration of $100 \mu \mathrm{g} / \mathrm{ml}$. Treatment with $100 \mu \mathrm{g} / \mathrm{ml}$ LTA increased the mRNA expression levels of the proinflammatory cytokines following $\sim 1 \mathrm{~h}$ incubation (Fig. 2).

LTA induces NF- $\kappa B$-driven transcriptional activity in BEAS- $2 B$ human bronchial epithelial cells. The role of NF- $\mathrm{kB}$, which is the principal transcription factor responsible for proinflammatory cytokine expression, was investigated in the BEAS-2B human bronchial epithelial cells treated with $100 \mu \mathrm{g} / \mathrm{ml}$ LTA. $\mathrm{NF}-\kappa \mathrm{B}$-driven transcriptional activity was measured at various time points in the LTA-treated cells following transfection 
A

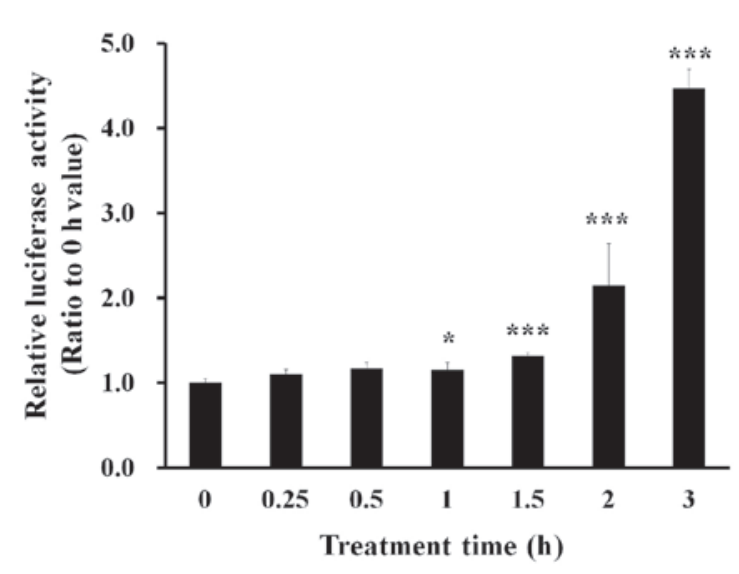

B

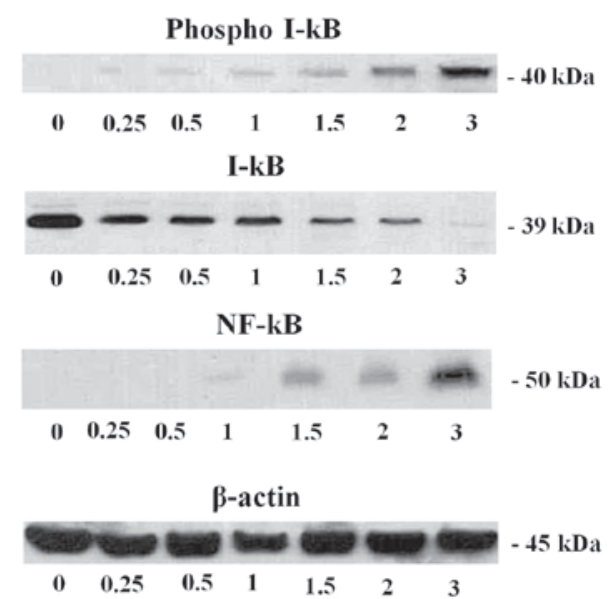

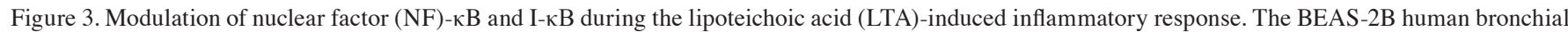

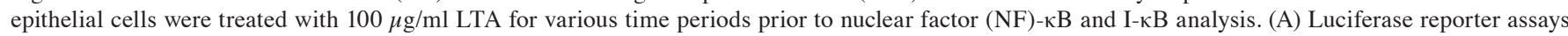

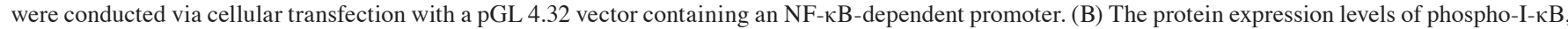

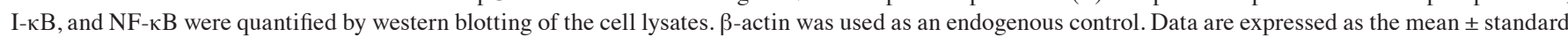
deviation. ${ }^{*} \mathrm{P}<0.05,{ }^{* * *} \mathrm{P}<0.001$, vs. $0 \mathrm{~h}$.

A

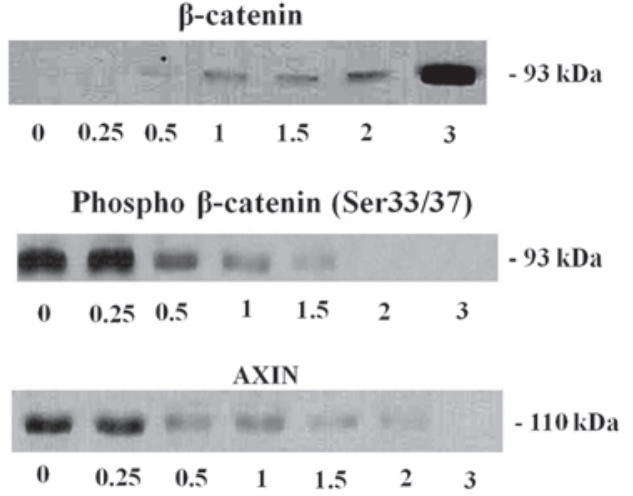

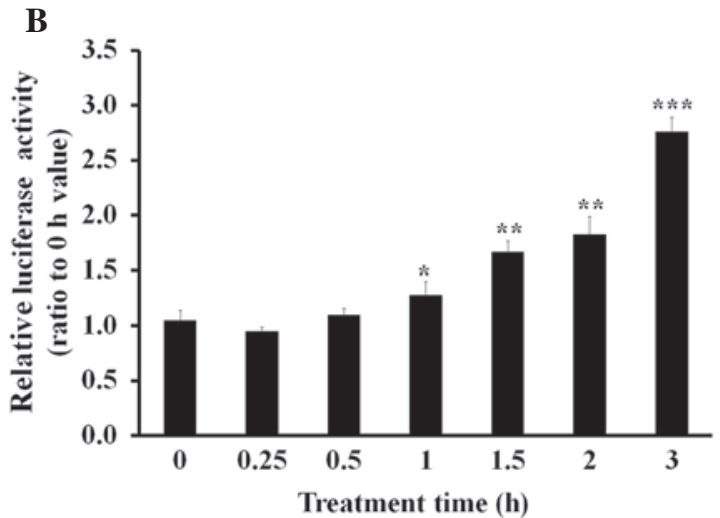

Figure 4. Modulation of $\beta$-catenin during the lipoteichoic acid (LTA)-induced inflammatory response. The activity and expression levels of $\beta$-catenin were analyzed in BEAS-2B human bronchial epithelial cells treated with $100 \mu \mathrm{g} / \mathrm{ml}$ LTA for various time periods. (A) The protein expression levels of total $\beta$-catenin, phosphorylated $\beta$-catenin (at Ser 33/37 residues), and AXIN were analyzed by western blotting. (3B) and (A) were obtained from the identical cellular extracts, and the same $\beta$-actin blot was used as the endogenous control of both. (B) Luciferase reporter assays were conducted by transfection with a TOP flash vector containing a $\beta$-catenin-dependent promoter. Data are expressed as the mean \pm standard deviation. ${ }^{*} \mathrm{P}<0.05,{ }^{* * *} \mathrm{P}<0.01$, and ${ }^{* * * *} \mathrm{P}<0.001, \mathrm{vs} .0 \mathrm{~h}$.

with a pGL 4.32 vector containing a luciferase gene linked to an NF- $\mathrm{NB}$-dependent promoter. The results demonstrated that $\mathrm{NF}-\kappa \mathrm{B}$-driven transcription increased $\sim 1 \mathrm{~h}$ following LTA treatment (Fig. 3A). Under the same experimental conditions, phosphorylation of $\mathrm{I}-\kappa \mathrm{B}$ increased $0.25-0.5 \mathrm{~h}$ following LTA treatment, whereas the protein expression levels of I- $\kappa \mathrm{B}$ were decreased (Fig. 3B). In addition, the protein expression levels of $\mathrm{NF}-\kappa \mathrm{B}$ increased $1 \mathrm{~h}$ following LTA treatment (Fig. 3B).

LTA upregulates $\beta$-catenin in BEAS-2B human bronchial epithelial cells. The BEAS-2B human bronchial epithelial cells were treated with $100 \mu \mathrm{g} / \mathrm{ml}$ LTA for various time periods. The results showed that the protein expression levels of $\beta$-catenin increased $0.5 \mathrm{~h}$ following treatment with LTA (Fig. 4A). Conversely, the phosphorylation levels of $\beta$-catenin at Ser 33/37 residues, as well as the expression levels of AXIN, a major component of the $\beta$-catenin degradation complex, were downregulated following treatment with LTA $(12,13)$. The transcriptional coactivator activity levels of $\beta$-catenin were measured using a TOP flash vector containing a luciferase gene linked to a $\beta$-catenin-dependent promoter (Fig. 4B). LTA upregulated both the activity and protein expression levels of $\beta$-catenin.

$\beta$-catenin knockdown decreases the activity and expression levels of $N F-\kappa B$ in LTA-treated BEAS-2B human bronchial epithelial cells. In order to investigate the effects of $\beta$-catenin on LTA-induced NF- $\kappa \mathrm{B}$ activity and expression, the BEAS-2B human bronchial epithelial cells were transfected with either control or $\beta$-catenin siRNA, and treated with LTA in order to induce $N F-\kappa B$ activity. The expression levels of $\beta$-catenin upregulated by LTA treatment were reduced following $\beta$-catenin siRNA transfection, as compared with control siRNA transfection, demonstrating that $\beta$-catenin is knocked down by $\beta$-catenin siRNA. Under the same experimental conditions, the expression levels of phospho I- $\kappa \mathrm{B}$ were signifi- 
A

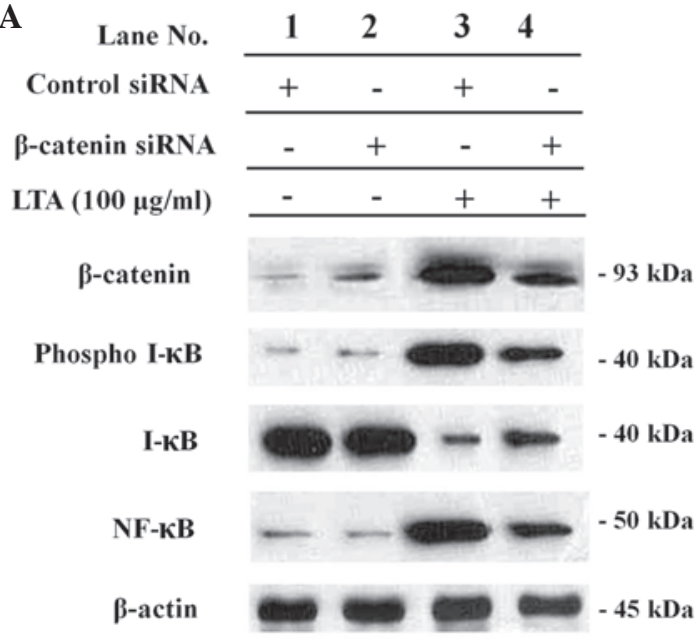

B

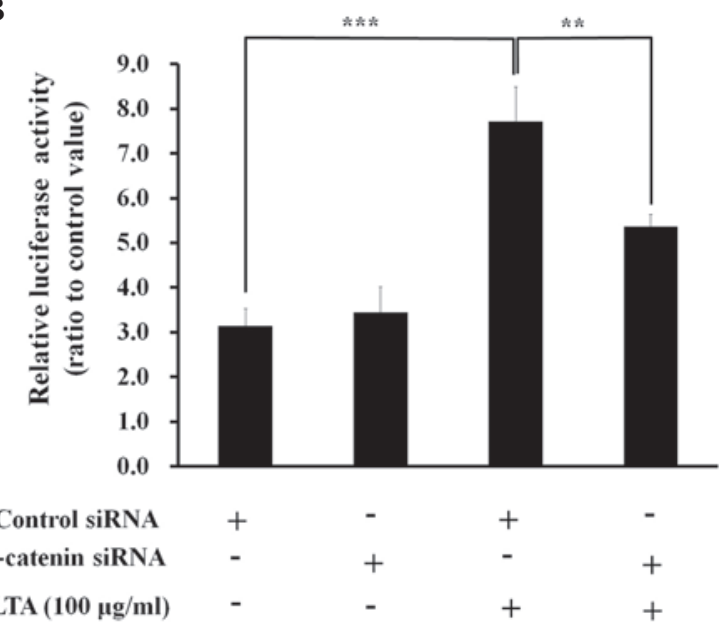

Figure 5. Effects of $\beta$-catenin knockdown on lipoteichoic (LTA)-induced nuclear factor (NF)-кB activity. The BEAS-2B human bronchial epithelial cells were transfected with either control or $\beta$-catenin small interfering (si)RNA for $18 \mathrm{~h}$, and stimulated with 0 or $100 \mu \mathrm{g} / \mathrm{ml}$ LTA for $3 \mathrm{~h}$. (A) The protein expression levels of the cell lysates were analyzed with $\beta$-actin as the endogenous control. (B) Luciferase reporter assays were conducted by transfection with a pGL 4.32 vector containing an NF-kB-dependent promoter. Data are expressed as the mean \pm standard deviation. ${ }^{* *} \mathrm{P}<0.01$, and ${ }^{* * * *} \mathrm{P}<0.001$ between the two groups.

A

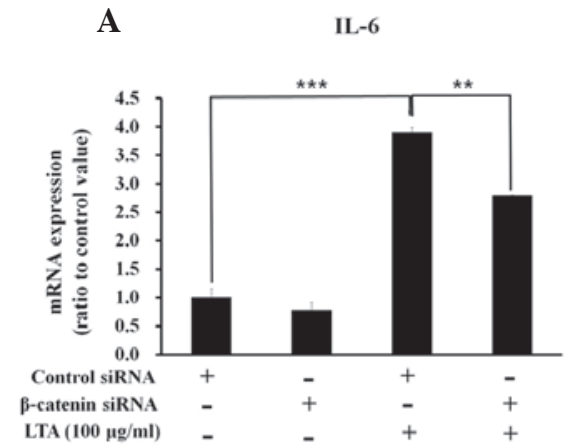

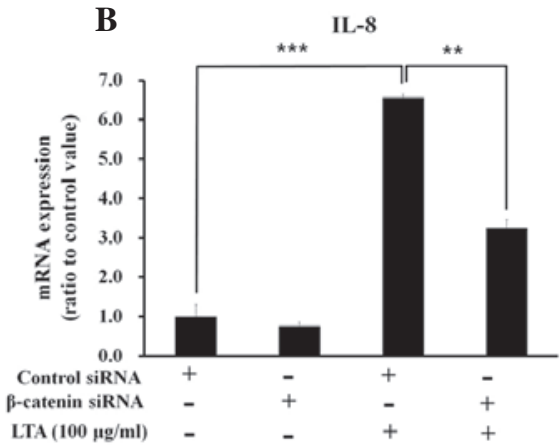

$\mathbf{E}$

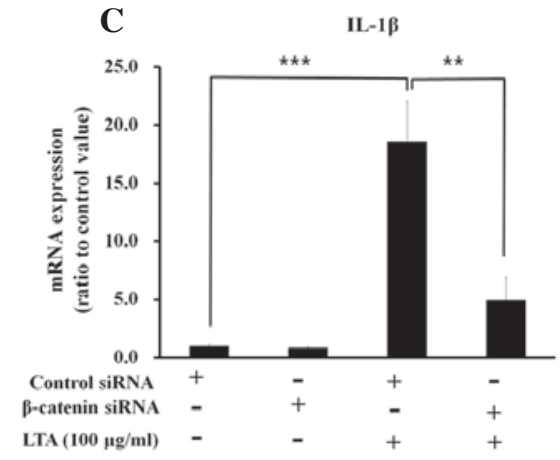

$\operatorname{LTA}(100 \mu \mathrm{g} / \mathrm{ml})$
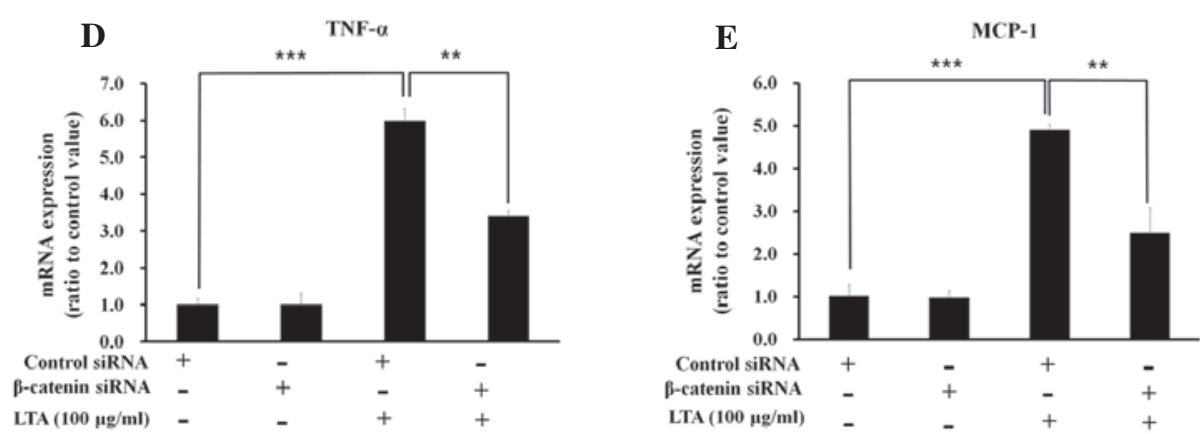

Figure 6. Effects of $\beta$-catenin knockdown on the lipoteichoic (LTA)-induced expression levels of proinflammatory cytokines. The BEAS-2B human bronchial epithelial cells were transfected with either control or $\beta$-catenin small interfering (si)RNA for $18 \mathrm{~h}$, and stimulated with 0 or $100 \mu \mathrm{g} / \mathrm{ml} \mathrm{LTA}$ for $3 \mathrm{~h}$. Total RNA was extracted for reverse transcription quantitative-polymerase chain reaction in order to quantify the expression levels of the proinflammatory cytokines: (A) interleukin (IL)-6; (B) IL-8, (C) Il-1 $\beta$; (D) tumor necrosis factor (TNF)- $\alpha$; (E) monocyte chemoattractant protein (MCP)-1.Data are shown as the ratio to the value of the control cells treated with $0 \mu \mathrm{g} / \mathrm{ml}$ LTA following control siRNA transfection. Data are expressed as the mean \pm standard deviation. ${ }^{* *} \mathrm{P}<0.01$ and ${ }^{* * *} \mathrm{P}<0.001$ between the two groups.

cantly reduced following $\beta$-catenin knockdown, whereas the expression levels of I- $\mathrm{KB}$ were increased, demonstrating an inverse correlation between the expression levels of I- $\mathrm{KB}$ and phospho-I- $\kappa \mathrm{B}$ (Fig. 5A, lanes 3 and 4). Similarly, the expression levels of NF- $\mathrm{kB}$ upregulated by LTA treatment were significantly reduced following $\beta$-catenin knockdown, demonstrating an inverse correlation between the expression

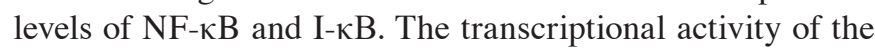
NF- $\kappa B$-dependent promoter, which was upregulated by LTA treatment, was also significantly reduced following $\beta$-catenin knockdown, demonstrating a correlation between the expression levels of the NF- $\mathrm{kB}$-dependent promoter and NF- $\mathrm{KB}$ (Fig. 5B).

$\beta$-catenin knockdown decreases the expression levels of proinflammatory cytokines in LTA-treated cells. In order to investigate the effects of $\beta$-catenin on the expression levels of LTA-induced proinflammatory cytokines, the expression 
levels of IL-6, IL-8, IL-1 $\beta$, TNF- $\alpha$ and MCP-1 were measured in the BEAS-2B human bronchial epithelial cells transfected with either control or $\beta$-catenin siRNA, both with and without LTA treatment (Fig. 6). The expression levels of the proinflammatory cytokines upregulated by LTA treatment were significantly reduced following $\beta$-catenin knockdown. These results indicate a correlation between the expression levels of $\mathrm{NF}-\kappa \mathrm{B}$, the $\mathrm{NF}-\kappa \mathrm{B}$-dependent promoter, and proinflammatory cytokines (Figs. 5 and 6).

\section{Discussion}

LTA is a major virulence factor that has an important role in infection and post-infection pathological events caused by gram-positive bacteria (2). The results of the present study confirmed that LTA induces the expression of proinflammatory cytokines in BEAS-2B human bronchial epithelial cells. In addition, LTA was able to increase the transcriptional activity of $\mathrm{NF}-\kappa \mathrm{B}$, as determined by a reporter assay of the $\mathrm{NF}-\kappa \mathrm{B}-$ dependent promoter, and increase the phosphorylation/degradation of $\mathrm{I}-\kappa \mathrm{B}$. These results demonstrated that LTA may modulate the expression levels of $\mathrm{I}-\kappa \mathrm{B}$ and $\mathrm{NF}-\kappa \mathrm{B}$, thereby upregulating proinflammatory cytokine expression in BEAS-2B human bronchial epithelial cells. NF- $\kappa \mathrm{B}$ is an important factor in the inflammation of bronchial epithelial cells exposed to various toxic compounds and pathogenic microorganisms (14-19). Therefore, ascertaining which genes or proteins modulate $\mathrm{NF}-\kappa \mathrm{B}$ may help identify therapeutic targets for the prevention and treatment of respiratory diseases mediated by bronchial inflammation.

In the present study, both the activity and protein expression levels of $\beta$-catenin were significantly increased in LTA-treated BEAS-2B human bronchial epithelial cells. Conversely, the phosphorylation levels of $\beta$-catenin at Ser 33/37 residues as well as the protein expression levels of AXIN, were decreased following treatment with LTA. Previous studies have reported that the activity and protein expression levels of $\beta$-catenin are post-translationally regulated via the $\mathrm{WNT} / \beta$-catenin signaling pathway $(12,13)$. When the $\mathrm{WNT} / \beta$-catenin signaling pathway is in the resting state, $\beta$-catenin is degraded by a degradation complex composed of AXIN, adenomatous polyposis coli, and glycogen synthase kinase $3 \beta$, which phosphorylates $\beta$-catenin at Ser $33 / 37$ residues creating a binding site for E3 ubiquitin, which leads to the ubiquitination and proteolytic degradation of $\beta$-catenin $(12,13)$. Conversely, activation of the WNT/ $\beta$-catenin signaling pathway results in the upregulation of $\beta$-catenin via its dephosphorylation at Ser 33/37 residues, preventing ubiquitination and proteolytic degradation $(12,13)$. The results of the present study demonstrated that $\beta$-catenin was upregulated by LTA treatment via the downregulation of AXIN, a component of the $\beta$-catenin degradation complex.

In order to confirm the role of $\beta$-catenin in the LTA-induced inflammatory response of bronchial epithelial cells, $\beta$-catenin was knocked down by $\beta$-catenin siRNA transfection. When $\beta$-catenin was knocked down, the protein expression levels of $\mathrm{NF}-\kappa \mathrm{B}$ were significantly reduced, suggesting the important role of $\beta$-catenin in the modulation of $\mathrm{NF}-\kappa \mathrm{B}$ expression. $\mathrm{NF}-\kappa \mathrm{B}$ downregulation following $\beta$-catenin knockdown in LTA-treated cells was accompanied by reduced phosphorylation/degradation of $\mathrm{I}-\kappa \mathrm{B}$. The transcriptional activity of the
$\mathrm{NF}-\kappa \mathrm{B}$-dependent promoter, which was upregulated by LTA, was also significantly reduced following $\beta$-catenin knockdown. In addition, the expression levels of LTA-induced proinflammatory cytokines were significantly reduced following $\beta$-catenin siRNA transfection, demonstrating a correlation between the expression levels of $\mathrm{NF}-\kappa \mathrm{B}$, the $\mathrm{NF}-\kappa \mathrm{B}$-dependent promoter, and proinflammatory cytokines. These results confirm that $\beta$-catenin has a significant role in the upregulation of $\mathrm{NF}-\kappa \mathrm{B}$ and proinflammatory cytokine expression during the inflammatory response to LTA.

Previous studies have suggested the importance of $\beta$-catenin in the inflammatory response induced by various pathogenic agents. Kim et al (20) reported that LPS caused $\beta$-catenin accumulation and nuclear translocation, followed by NADPH oxidation in RAW 264.7 macrophage cells, and murine bone marrow-derived macrophages. Furthermore, a previous study demonstrated that LPS-induced proinflammatory cytokine expression in bronchial epithelial cells was suppressed by $\beta$-catenin knockdown, suggesting an important role for $\beta$-catenin in the LPS-induced inflammatory response (10). In addition, $\beta$-catenin upregulated the expression levels of inflammatory cytokines in THP-1 human monocytic cells stimulated by Der $\mathrm{p} 1$, a major house dust mite allergen (21). TNF- $\alpha$-induced proinflammatory cytokine expression in bronchial epithelial cells has also been shown to be suppressed by $\beta$-catenin siRNA transfection (unpublished data). The present study provides evidence that $\beta$-catenin modulates the expression levels of $\mathrm{NF}-\kappa \mathrm{B}$ and inflammatory cytokines in BEAS-2B human bronchial epithelial cells stimulated by LTA, a major virulence factor of gram-positive bacteria. The results of the present study are concordant with those of previous studies, suggesting a major role for $\beta$-catenin in the regulation of the inflammatory response.

The precise mechanism underlying $\beta$-catenin modulation of inflammatory signaling remains unclear. However, the similarities in the effects of $\beta$-catenin, and the variety in upstream signaling molecules between diverse inflammatory inducers such as LTA, LPS, and TNF- $\alpha$, suggest that the target of $\beta$-catenin may be located downstream of the inflammatory signaling pathway. LPS (10), LTA (present study), and TNF- $\alpha$ (unpublished data) induce the phosphorylation and degradation of $\mathrm{I}-\kappa \mathrm{B}$, followed by the upregulation of NF- $\kappa \mathrm{B}$ expression, suggesting that the target of $\beta$-catenin may be associated, directly or indirectly, to the phosphorylation/degradation of $\mathrm{I}-\kappa \mathrm{B}$. Further studies are required in order to elucidate the precise molecular mechanism underlying $\beta$-catenin activity, but the results of the present study suggest that $\beta$-catenin may be a regulator of bronchial inflammation. These results may prove useful in the prevention and treatment of respiratory diseases.

\section{Acknowledgements}

The present study was supported by a grant from the Basic Science Research Program of the National Research Foundation of Korea (grant no. NRF-2013R1A1A2A10006146).

\section{References}

1. Schneewind $\mathrm{O}$ and Missiakas D: Lipoteichoic acids, phosphate-containing polymers in the envelope of gram-positive bacteria. J Bacteriol 196: 1133-1142, 2014. 
2. Ginsburg I: Role of lipoteichoic acid in infection and inflammation. Lancet Infect Dis 2: 171-179, 2002.

3. Opal SM and Cohen J: Clinical gram-positive sepsis: Does it fundamentally differ from gram-negative bacterial sepsis? Crit Care Med 27: 1608-1616, 1999.

4. Sriskandan S and Cohen J: Gram-positive sepsis. Mechanisms and differences from gram-negative sepsis. Infect Dis Clin North Am 13: 397-412, 1999.

5. Schmeck B, Huber S, Moog K, Zahlten J, Hocke AC, Opitz B, Hammerschmidt S, Mitchell TJ, Kracht M, Rosseau S, et al: Pneumococci induced TLR- and Racl-dependent NF-kappaB-recruitment to the IL-8 promoter in lung epithelial cells. Am J Physiol Lung Cell Mol Physiol 290: L730-L737, 2006.

6. Kawai $\mathrm{T}$ and Akira S: Toll-like receptors and their crosstalk with other innate receptors in infection and immunity. Immunity 34: 637-650, 2011.

7. Lee IT, Lee CW, Tung WH, Wang SW, Lin CC, Shu JC and Yang CM: Cooperation of TLR2 with MyD88, PI3K, and Rac1 in lipoteichoic acid-induced cPLA2/COX-2-dependent airway inflammatory responses. Am J Pathol 176: 1671-1684, 2010.

8. Bradding P, Roberts JA, Britten KM, Montefort S, Djukanovic R, Mueller R, Heusser $\mathrm{CH}$, Howarth $\mathrm{PH}$ and Holgate ST: Interleukin-4, -5 , and -6 and tumor necrosis factor-alpha in normal and asthmatic airways: Evidence for the human mast cell as a source of these cytokines. Am J Respir Cell Mol Biol 10: 471-480, 1994.

9. Moon RT, Bowerman B, Boutros M and Perrimon N: The promise and perils of Wnt signaling through beta-catenin. Science 296: 1644-1646, 2002.

10. Jang J, Ha JH, Chung SI and Yoon Y: B-catenin regulates NF- $\kappa B$ activity and inflammatory cytokine expression in bronchial epithelial cells treated with lipopolysaccharide. Int J Mol Med 34: 632-638, 2014

11. Livak KJ and Schmittgen TD: Analysis of relative gene expression data using real-time quantitative PCR and the 2(-Delta Delta C(T)) Method. Methods 25: 402-408, 2001.

12. Cadigan KM and Liu YI: Wnt signaling: Complexity at the surface. J Cell Sci 119: 395-402, 2006.

13. Willert K and Nusse R: Beta-catenin: A key mediator of Wnt signaling. Curr Opin Genet Dev 8: 95-102, 1998.
14. Profita M, Bonanno A, Montalbano AM, Ferraro M, Siena L, Bruno A, Girbino S, Albano GD, Casarosa P, Pieper MP and Gjamarkaj M: Cigarette smoke extract activates human bronchial epithelial cells affecting non-neuronal cholinergic system signalling in vitro. Life Sci 89: 36-43, 2011.

15. Tal TL, Simmons SO, Silbajoris R, Dailey L, Cho SH, Ramabhadran R, Linak W, Reed W, Bromberg PA and Samet JM: Differential transcriptional regulation of IL-8 expression by human airway epithelial cells exposed to diesel exhaust particles. Toxicol Appl Pharmacol 243: 46-54, 2010.

16. Pylkkänen L, Stockmann-Juvala $H$, Alenius $H$, Husgafvel-Pursiainen K and Savolainen K: Wood dusts induce the production of reactive oxygen species and caspase-3 activity in human bronchial epithelial cells. Toxicology 262 : 265-270, 2009.

17. Bossios A, Gourgiotis D, Skevaki CL, Saxoni-Papageorgiou P, Lötvall J, Psarras S, Karpathios T, Constandopoulos AG, Johnston SL and Papadopoulos NG: Rhinovirus infection and house dust mite exposure synergize in inducing bronchial epithelial cell interleukin-8 release. Clin Exp Allergy 38: 1615-1626, 2008.

18. Ishibashi $Y$ and Nishikawa A: Role of nuclear factor-kappa B in the regulation of intercellular adhesion molecule 1 after infection of human bronchial epithelial cells by Bordetella pertussis. Microb Pathog 35: 169-177, 2003.

19. Thomas LH, Friedland JS, Sharland M and Becker S: Respiratory syncytial virus-induced RANTES production from human bronchial epithelial cells is dependent on nuclear factor-kappa B nuclear binding and is inhibited by adenovirus-mediated expression of inhibitor of kappa B alpha. J Immunol 161: 1007-1016, 1998.

20. Kim JS, Yeo S, Shin DG, Bae YS, Lee JJ, Chin BR, Lee $\mathrm{CH}$ and Baek SH: Glycogen synthase kinase 3beta and beta-catenin pathway is involved in toll-like receptor 4-mediated NADPH oxidase 1 expression in macrophages. FEBS J 277: 2830-2837, 2010.

21. Jang J, Ha JH, Kim SM, Kim W, Kim K, Chung SI and Yoon Y: $\beta$-catenin mediates the inflammatory cytokine expression induced by the Der $\mathrm{p} 1$ house dust mite allergen. Mol Med Rep 9: 633-638, 2014. 